\title{
LIMITES DO USO DE ALGEMAS A CASOS EXCEPCIONAIS PELO TRABALHO DA POLÍCIA: UM EQUILIBRIO DESESTABILIZADOR APRECIADO PELO STF
}

\section{LIMITS HANDCUFFS USE OF EXCEPTIONAL CASES, THE POLICE WORK: A BALANCE DESTABILIZING APPRECIATED BY STF}

\author{
${ }^{1}$ Francisco Das Chagas Sampaio Medina \\ ${ }^{2}$ Paulo Roberto Meyer Pinheiro
}

\section{RESUMO}

O objetivo do presente estudo é analisar de que modo a influência de teorias hermenêuticas, voltadas à investigação sobre o conceito de norma jurídica, tem causado impactos na interpretação e aplicação da Constituição brasileira de 1988 pelo Poder Judiciário, em especial pelo Supremo Tribunal Federal. A decisão da Corte com a Súmula Vinculante ${ }^{\circ} 11$ do STF, deixar mais explicitada o seu entendimento sobre o uso generalizado de algemas, diante do que considerou nos últimos tempos de uso abusivo, em que pessoas detidas vêm sendo algemadas e expostas, aos flashes da mídia. Somente lícito em casos excepcionais, restando justificado ante a periculosidade do agente ou risco concreto de fuga. O exame dessa relação se dará com atenção à mudança de paradigma na compreensão do que seja a própria norma jurídica, considerando a conexão existente entre o texto oferecido como produto do trabalho do legislador e o resultado apresentado pelo aplicador do direito quando diante de um caso concreto.

Palavras-chave: Hermenêutica, Súmula vinculante, Caso concreto, Colisão de direitos, Ponderação

\begin{abstract}
The aim of this study is to examine how the influence of hermeneutical theories, focused on research on the concept of rule of law, has impacted the interpretation and application of the Brazilian Constitution of 1988 by the judiciary, especially the Supreme Court. The decision of the Court with the Binding Precedent 11 of the Supreme Court, leave more explicit their understanding of the widespread use of handcuffs, before he considered in recent times of abuse, in which detainees have been handcuffed and exposed to media flashes . Only permitted in exceptional cases, leaving justified before the dangerousness of the offender or concrete flight risk. The examination of this relationship will be with attention to the paradigm shift in the understanding of what is the proper legal standard, considering the connection between the text offered as the legislative work of the product and the result presented by the right applicator when faced with a concrete case.
\end{abstract}

Keywords: Hermeneutics, Binding precedent, If concrete, Rights collision, Weighting

\footnotetext{
${ }^{1}$ Mestrando em Direito Constitucional pela Universidade de Fortaleza - UNIFOR, Ceará (Brasil). Professor da Universidade de Fortaleza - UNIFOR, Ceará (Brasil). E-mail: fcomedina.adv@ hotmail.com

2 Mestrando em Direito Constitucional pela Universidade de Fortaleza - UNIFOR, Ceará (Brasil). E-mail: paulomyr@gmail.com
} 


\section{INTRODUÇÃO}

A discussão acerca da Hermenêutica Constitucional é tema de grande importância para o Direito Contemporâneo, muito pelo fato de que é através dela que se delimitam o conceito, a extensão e a aplicabilidade dos reconhecidos Direitos Fundamentais positivados pela norma jurídica suprema. Além disso, a nova dogmática jurídica reconhece um método contemporâneo de explicação do direito positivo, consagrando a construção da norma em regras e princípios. Dessa forma, moldando o conteúdo normativo pela axiologia principiológica. Neste sentido, a pergunta que norteia a presente pesquisa é: Como o Supremo Tribunal Federal realiza o controle dos valores da Constituição brasileira?

Nunca houve tanto debate em torno da hermenêutica constitucional quanto na realidade jurídica atual, em especial no Brasil, onde o controle de constitucionalidade, que sempre teve sua tradição difusa, passou a dar lugar ao critério concentrado desde o advento da Constituição de 1988.

Neste contexto, acrescentamos a estes dados a Súmula Vinculante número 11 de 2008 do Supremo Tribunal Federal. Essa jurisprudência vem causando um verdadeiro desentendimento perante os organismos de segurança pública, as unidades criminais do próprio Poder Judiciário e aos membros do Ministério Público que age nas Varas Criminais, pois tal medida tem impossibilitado o agente, em certos casos, de fazer uso de meio de contenção para a condução do preso quando publicamente.

Depois da inércia do Poder Executivo por mais de 24 anos sem regulamentar o uso de algemas, previsto pela Lei de Execuções Penais (Lei Federal $n^{\circ}$ 7210/84), assumiu a responsabilidade e aprovou no dia 13 de agosto 2008 a Súmula Vinculante $n^{\circ} 11$, da qual limita o uso de algemas, licitamente, a casos excepcionais de resistência, de fundado receio de fuga ou de perigo à integridade física do policial ou alheia, por parte do preso ou de terceiros.

Prevê a súmula, ainda, a aplicação de penalidades pelo abuso no seu uso indevido, pois se consubstanciaria em constrangimento físico e moral do preso, caso não seja devidamente justificada por escrito, podendo acarretar em responsabilidades disciplinar, civil e penal do policial e de nulidade da prisão ou do ato processual, sem prejuízo da responsabilidade civil do Estado.

O instituto da Súmula Vinculante foi criado pela Emenda Constitucional $\mathrm{n}^{\circ} 45$ de 2004, da qual objetiva pacificar a discussão de questões examinadas nas instâncias inferiores do Judiciário, visando diminuir o número de recursos que chegam às instâncias superiores e ao 
STF, permitindo a sua resolução na primeira instância. O STF editou uma súmula, baseando-se no julgamento HC 91952 de Habeas Corpus, no qual o Plenário anulou a condenação do pedreiro Antônio Sérgio da Silva pelo Tribunal do Júri, na cidade de Laranjal Paulista (São Paulo) na qual o julgou por homicídio triplamente qualificado.

O STF anulou a condenação argumentando que o Tribunal do Juri violou o princípio da dignidade da pessoa humana, em virtude de ter mantido o réu algemado diante aos jurados durante todo o julgamento do réu, sem que a juíza tivesse apresentado justificativa convincente para o fato, influenciando na condenação.

A súmula consolida entendimento do STF perante o cumprimento de legislação que trata do assunto, como: artigo $1^{\circ}$, inciso III da Constituição Federal e de vários outros incisos da mesma Carta Magna que dizem respeito à dignidade humana, além também dos artigos 284 e 29 do Código de Processo Penal, além dos dispostos no parágrafo $3^{\circ}$ do artigo 474 do mesmo código, alterado pela Lei $\mathrm{n}^{\mathrm{o}} 11.689 / 08$ e no parágrafo $1^{\circ}$ do artigo 234 do Código de Processo Penal Militar.

Com a determinação, a utilização de algemas passou ser excepcional, o último recurso diante da possibilidade real de fuga e da periculosidade do agente. Não há dúvidas de que o uso de algemas exacerbado vulnera o estado de privação da liberdade com consequências de ordem física e moral, distanciando do Estado Democrático de Direito e contribuindo para o aumento do sensacionalismo pela mídia.

O objetivo da mais alta Corte do país é de acabar com os abusos relacionados ao emprego de algemas em pessoas presas. A razão seria de que o réu algemado na frente dos jurados poderia influenciar no pré-julgamento do acusado. Assim, o Supremo Tribunal Federal visa evitar a utilização de algemas, desestimulando o sensacionalismo midiático e a influência do uso das algemas no julgamento. Porém, uma inovação a Súmula possibilitaria a anulação da prisão ou ato processual e punição do agente infrator, em virtude do uso indevido das algemas.

A recomendação dirige-se aos entes públicos, no qual a polícia não faça nenhum tipo de apresentação do preso ou o submeta a algum tipo de execração ou vergonha. $O$ preso não pode ser exibido como um troféu pela boa atuação da polícia. O Estado não pode violar a intimidade, a imagem, a vida privada e a dignidade das pessoas sob o argumento singelo de que vai combater melhor a criminalidade. 
Mais do que discutir o resultado do julgamento, este trabalho pretende, a partir da hermenêutica jurídico-constitucional e da teoria dos direitos fundamentais, examinar como o Supremo chegou a esse resultado. A hermenêutica constitucional aponta para o caráter constitutivo da decisão judicial e da necessária sobreposição entre o fato e os elementos normativos, que servirão para a construção da decisão que julgará o caso. Já que há uma cisão na composição da norma jurídica em regras e princípios, estes últimos passam a externar valores que compõem, justamente, a cláusula de abertura, ou de adequação do direito à realidade social que deve ser ordenada.

\section{CONTEXTUALIZAÇÃO HISTÓRICA HERMENEUTICA}

A compreensão de linguagem que possuímos no Ocidente e a própria compreensão da linguagem - hermenêutica textual - é fruto de uma longa tradição filológica (BAKHTIN, 1995; SCHLEIERMACHER, 2010). Essa tradição influenciou não somente o que entendemos por texto, livro, escrito, sentido, autor, mas, principalmente, o método de aproximação do exegeta, do intérprete, aos textos, livros, escritos, sentidos e autores concretos que constroem a nossa história.

Schleiermacher (1768-1834) define a interpretação como sendo toda compreensão do discurso estranho (SCHLEIERMACHER, 2010, p. 26). O autor aponta, porém, que falta a interpretação (àquela que estamos, praticamente, fadados, desde o primeiro momento que entramos em contato com o outro pela linguagem) uma construção sistemática de sua significação; falta uma definição da hermenêutica e de seu primado (sobre a gramática, a crítica e a própria filologia) conforme as regras, com rigor filosófico. Isso se torna necessário, para Schleiermacher, a partir da percepção de que a hermenêutica teológica e a literária (que abarcam a filologia dos clássicos, tocando o que se havia de literatura, teatro e filosofia até então) lidam com objetos diversos, mas constituem apenas divisões de uma mesma arte, a hermenêutica.

No entanto, a Hermenêutica Jurídica não é completamente a mesma coisa. Ela lida, na maior parte das vezes, com a determinação da extensão da Lei, isto é, com a relação dos princípios gerais os quais não foram concebidos claramente (SCHLEIERMACHER, 2010, p. 29). Schleiermacher (2010) pensa, pela primeira vez, a hermenêutica como sendo uma matéria independente, como sendo uma Kusntlehre, vale dizer, de uma 'tecnologia' que não se limita mais a uma simples coleção de operações desarticuladas (RICOEUR, 2008, p. 26). Não por 
menos, é considerado o pai da hermenêutica moderna, que seria a hermenêutica filosófica, cujo papel é refletir sobre as possibilidades de sua existência prático-concreta na formação do conhecimento e nas consequências concretas de sua realização (interpretação de discursos teológicos, filosóficos, entre outros). Por mais que Schleiermacher (2010) tenha dado algum relevo à hermenêutica jurídica, sua vasta obra centra-se nas subdivisões bíblico-exegéticas, teológicas, filosóficas e clássico-artísticas da hermenêutica.

Ricoeur (2008) aponta que as reflexões hermenêuticas de Schleiermacher levaram ao desenvolvimento da matéria como sendo a reflexão da possibilidade epistemológica das ciências humanas e isso se coroa com a obra de Dilthey (1833-1911), que definiu a cisão entre as ciências humanas e exatas como uma cisão entre compreensão e explicação - os respectivos papéis dessas ciências. O que está aqui em questão é a delimitação provisória das Ciências Humanas ante as Ciências Naturais por meio de traços característicos seguros (DILTHEY, 2010, p. 19). Essa tarefa epistemológica ganha, em Dilthey (2010, p. 167), a grande vantagem de contar com o que ele chama "crítica da razão histórica", que seria saber como a construção do mundo histórico no sujeito torna possível um saber sobre a realidade espiritual.

Por lidar com evoluções históricas e por opor ciências humanas e naturais, Dilthey (2010, p. 45) vê no direito um papel mais importante para a compreensão hermenêutica que Schleiermacher: [...] surge a classe à parte dos juristas; essa classe representa o povo em sua função jurídica; a formação conceitual transforma-se, então, no instrumento do desenvolvimento jurídico: ela concebe princípios, diretrizes fundamentais, isto é, definições nas quais os outros princípios estão dados; o caráter científico da jurisprudência baseia-se na descoberta desses princípios fundamentais e a jurisprudência se torna cada vez mais a base do aperfeiçoamento do direito por meio da legislação. Sobre a influência da escola histórica no Direito, em especial comentando a obra de Savigny.

O caminho dá uma volta quando desce da reflexão científico-epistemológica e atinge aspectos do cotidiano, do "mundo" e da "presença" do homem na obra de Heidegger (18891976). Em sua busca pelo significado do ser, Heidegger (1999, p. 203) afirma que o ser do homem, o Dasein ou presença (conforme seus tradutores brasileiros) é ponto essencial na busca do sentido do ser, pois compreender o ente ou o ser é algo que só se dá pelo ser do homem, o qual é enquanto compreende: A presente investigação já se deparou com esse compreender originário sem, no entanto, permitir que aforasse explicitamente como tema. Dizer que a presença existindo é o seu pré significa, por um lado, que o mundo é 'presença', a sua presença é o serem. Este é igualmente 'presença' como aquilo em virtude de que a presença é. 
Nesse em virtude de, o ser-no-mundo existente se abre como tal. Chamou-se essa abertura de compreender. [...] Dizer que o em virtude de e a significância se abrem na presença significa fizer que a presença é um ente em que, como ser-no-mundo, está em jogo seu próprio ser.

Assim, para Heidegger (1999), a questão histórica do compreender ganha relevo sobre a questão epistemológica, uma vez que o homem não só é; esse ser é ser em compreensão, ser compreendendo, mas o é de maneira concreta, localizada, estando sempre "em" (ser em), no caso, "no mundo", donde "ser no mundo". A investigação de ser e tempo aponta que o ser do homem, o qual é enquanto compreende, sempre se encontra no mundo e constitui um "ser para morte". Assim, tanto o mundo quanto a morte revelam para o homem que ele é no tempo - mas não a compreensão "cotidiana" do tempo e, sim, uma compreensão fundamental de tempo, que coloca o homem em uma história concreta e que aproxima o seu ser com o tempo que é condição, mas também resultado da compreensão desse ser.

Heidegger não mais insistiu na mesma direção dessas investigações hermenêuticas após a sua "virada" (Kehre), conturbada por eventos biográficos obtusos e uma aproximação mais radical da metafísica (“destruição da metafísica”) e do niilismo de Nietzsche - refletindo sobre a técnica e sobre a possibilidade de continuarmos a filosofar pela linguagem.

Ainda na linhagem alemã e influenciado tanto pelas obras de Schleiermacher (2010) e Dilthey (2010) quanto pela de Heidegger (1999), é preciso citar Gadamer (1900-2002) como - muito provavelmente - o maior hermeneuta da filosofia na segunda metade do século XX. Em sua magnum opus, Gadamer (2007) retoma a problemática de Schleiermacher de uma teoria geral da hermenêutica, que ele chama "projeto universal" da hermenêutica, bem como a problemática epistemológica de Dilthey, a tensão entre explicar e compreender como tensão entre o próprio método e a obtenção da verdade e, enfim, o primado ontológico do papel da compreensão no ser do homem com base na obra de Heidegger, em especial, a partir de sua formulação do "círculo hermenêutico" em ser e tempo.

Em verdade e método, Gadamer (2007) formula uma teoria da hermenêutica em três níveis: o artístico (Kant, Schleiermacher), o histórico (Hegel, Dilthey) e o linguísticoontológico (Heidegger), unindo os pontos referenciais teóricos anteriormente apresentados. Ele retoma uma concepção grega do diálogo na sua teorização hermenêutica: o que constitui verdadeiramente o fenômeno hermenêutico originário é que não existe nenhum enunciado que não possa ser compreendido como resposta a uma pergunta, e é só assim que ele pode realmente ser compreendido (GADAMER, 2002, p. 263). Essa formulação quase "formal" da 
hermenêutica - formal, porém prática, pois a concepção de "pergunta-resposta" respeita uma lógica dialogal concreta - permite a Gadamer (2007) uma teorização verdadeiramente universal de hermenêutica, capaz de abarcar uma infinitude de eventos que utilizam a lógica perguntaresposta na sua constituição, sendo a própria interpretação vista como o evento ontológico de apropriação de um texto. Essa concepção ressalta a alteridade entre o texto, sua origem, sua história (a tradição) e o leitor (RICOEUR, 2011). Não à toa, Gadamer (2007) atribui à hermenêutica jurídica um papel "fundamental" na construção do entendimento moderno da própria hermenêutica e no processo concreto de apropriação: É verdade que o jurista sempre deve ter em mente a lei em si mesma. Mas seu conteúdo normativo deve ser determinado em relação ao caso em que deve ser aplicado. E para determinar com exatidão esse conteúdo não se pode prescindir de um conhecimento histórico do sentido originário, e é só por isso que o intérprete jurídico leva em conta o valor posicional histórico atribuído a uma lei em virtude do ato legislativo (GADAMER, 2007, p. 429).

Não há, na hermenêutica jurídica, uma tradição sistematizadora como na hermenêutica filosófica. O fato, porém, de haver uma maior consciência da importância da hermenêutica nos últimos anos somente comprova o outro fato de que, se está correto o brocado segundo o qual ubi societas ibijus, também é correto que ubi jus ibi interpretatio.

O objetivo não é mostrar como cada tradição jurídica primitiva interpretava as suas leis. Nossa tese é que, de modo geral, nas tradições antigas, a interpretação era algo intrínseco ao próprio fenômeno jurídico, ao corpo de leis, à práxis jurídica que compunha e às pessoas com acesso a tal "direito" (como a figura dos pretores e jurisconsultos, na Roma Antiga, por exemplo). Isso significa dizer que a interpretação jurídica era elemento constituinte do próprio direito, como se, com a lei, viesse sua interpretação - uma normatividade do sentido que se dava pela pureza do significado a ser encontrado na letra da lei.

A partir da construção da ideia de "sistema", que teve um longo desenvolvimento na nossa tradição romano-germânica (FERRAZ JUNIOR, 2008), a hermenêutica jurídica pode ser situada como a ferramenta capaz de dar nexo aos diversos elementos constituintes desse sistema, como o fator que liga - em uma linguagem teubeneriara (TEUBENER, 1993) - os subsistemas legal, jurisprudencial e doutrinário em um verdadeiro hiperciclo.

A não sistematização da hermenêutica jurídica dificulta, pois, olhar-se como uma "matéria" - e, se é possível falar de hermenêutica jurídica como matéria, é de modo secundário e a partir do ponto paradigmático de Hans Kelsen. 


\subsection{A reviravolta hermenêutica dos princípios}

Interessante o fato de que, quando Dworkin (2010, p. 35) vai apresentar sua teoria dos princípios, ele já a qualifica como um "ataque geral contra o positivismo".

Como vimos, há, para a hermenêutica jurídica, um interesse especial na concepção de norma, principalmente a partir da obra de Kelsen, que colocou a norma jurídica como o “objeto" de estudo jurídico em questão. Assim, uma teoria que atinja a concepção de norma balança a teoria da interpretação jurídica; é exatamente o que faz Dworkin (2010) ao afirmar que há dois tipos de norma: regras e princípios, e que há diferentes tipos de caso, regidos por diferentes tipos de norma - é a famosa teoria dos hard cases.

Para uma concepção da influência da teoria dos princípios na hermenêutica jurídica, não é tão interessante reconstruir a própria noção de "princípio" para essa teoria, mas localizála na "história" da teoria do direito e ver como ela influencia a práxis interpretativa do direito.

A teoria dos princípios surge em uma onda "pós-positivista" e corresponde, em muitos pontos, à influência que o tridimensionalismo teve no Brasil, pela teoria de Reale (1999). De fato, ainda em Dworkin (2010), há uma relação muito forte com as noções de valor e de princípio, apesar de estas não se confundirem. Reale (1999, p. 67) questiona o primado da norma no direito, dizendo que esta deveria ser vista em relação com os fatos e os valores em uma dialética da "implicação-polaridade". Dworkin (2010), diferentemente, relativiza o purismo da norma em sua concepção kelseniano-hartiana, permitindo que uma noção mais genérica, mais abrangente de norma, que é o princípio, fosse também considerada uma "norma" como as regras.

Desse passo fundamental, segue-se uma caminhada que é a bem conhecida teoria de Dworkin (2010), que abrange uma concepção moral de "juiz Hércules”, a hipótese da "única resposta correta", entre outros termos próprios de sua guinada antipositivista. É preciso ressaltar que essa sua guinada é uma virada hermenêutica justamente, pois a brecha que o autor abriu foi não somente na interpretação de textos, como também na própria interpretação de casos concretos (se são hard ou não...).

A teoria dos princípios ganha uma sistematização maior em Alexy (2008). Para ele, a aplicação de princípios segue um método específico, que se torna um verdadeiro dogma hermenêutico - para nossa Suprema Corte, inclusive, ainda que muitas vezes aplicado de modo bastante pessoal por alguns juízes e ministros -, que ficou conhecido por “sopesamento". Alexy (2008) propõe, para a aplicação de princípios em casos concretos que 
não podem ser resolvidos por regras em sua estrutura "tudo ou nada" (hard cases), um método trifásico que mede a aplicabilidade e direciona o uso de princípios constitucionais ou supraconstitucionais em casos concretos.

A principal diferença a ressaltar - a nosso ver - entre Alexy e Dworkin é que, para Alexy (2001), a decisão leva em conta o papel da argumentação e da retórica na formação da decisão final; não há que se falar em uma única decisão, mas em um jogo discursivo que serve para formar e fundamentar opiniões.

Como afirmado, a grande importância dessa teoria para a hermenêutica jurídica é a de deslocar o papel da norma, para permitir que se leia em seu texto mais que simplesmente uma "norma objeto" de um dever ser estático, ampliando a concepção de direito para uma análise mais minuciosa de "valores" e "princípios" de outras áreas, que influenciam, direta ou indiretamente, decisões cotidianas nos tribunais.

Defender-se uma liberdade hermenêutica, com amplos poderes para se realizar a interpretação da Constituição, de maneira que lhe seja garantida a vitalidade, a fatibilidade e a eficácia suficiente para se realizar social e historicamente como o projeto da associação política. Desde essa perspectiva, tais poderes convertem o STF em constituinte do ponto de vista axiológico-normativo, como moderador do ponto de vista político-social, como legislador do ponto de vista legal e como juiz do ponto de vista normativo-social.

O STF, como Corte Constitucional brasileira, ocupa uma posição central e especial entre os órgãos constitucionais da República Federativa do Brasil. Talvez ele represente, como nenhum outro, a melhor e mais avançada conquista do Estado brasileiro desde sua independência em 1821. Essa relevância foi consagrada na CRFB de 1981 quando lhe atribuiu os poderes e as competências que ostenta. Ademais, o STF, como todo órgão que exerce o poder numa sociedade democrática e no Estado de Direito, está permanentemente sob o controle democrático da sociedade, pelos olhos, principalmente, da mídia, e sempre precisa da necessária quota de legitimidade e do reconhecimento das outras instituições democráticas.

Então, como limitar os poderes hermenêuticos? E quais seriam os limites dos poderes da hermenêutica constitucional assim formulada?

O primeiro limite consiste no fato de que o STF também está vinculado às regras e diretrizes, aos deveres comuns a todo órgão e autoridade jurisdicional. Aliás, como o STF é um órgão composto de Ministros, eles também têm os deveres que todo juiz singular possui.

Um segundo limite seriam as próprias regras e diretrizes que o sistema tem, ou seja: como se produz uma norma; a própria regra; as diretrizes do sistema normativo; os princípios 
do sistema jurídico nacional. Isso também limita os Ministros, na medida em que estes não podem resolver um caso concreto baseando-se numa decisão jurídica de outro país.

O terceiro limite é a moral positiva, isto é, a moralidade socialmente predominante. O STF está vinculado e limitado pela tese hermenêutica da compreensão do que se entende como direito justo e injusto, correto e incorreto. Além disso, o STF também tem a capacidade de dar à moral positiva um impulso de progresso. Em outras palavras, a moral positiva, somada à cultura e à pré-compreensão cultural, dão ao STF a responsabilidade de levar a sociedade e a Constituição para frente, e também a possibilidade de realizar interpretações evolutivas, não permitindo, todavia, que se façam rupturas ou se abandone a vontade de Constituição (MIRANDA, 1999).

O quarto limite diz respeito à própria existência de outros poderes e as suas respectivas competências. Está claro que uma Corte Constitucional não pode desconhecer a competência que os outros poderes possuem.

O quinto limite consiste no fato de que o Supremo Tribunal Federal precisa apresentar um discurso justificador ou justificativo (é a argumentação jurídica). Ele deve esclarecer o motivo pelo qual tal decisão é constitucionalmente correta, moral e conveniente para a Constituição e para a comunidade (MIRANDA, 1999). A contra crítica poderia alegar que esses argumentos não seriam suficientes. Porém, tal crítica estaria ligada ao processo de desnaturalização do Supremo e, por isso, contrário à Constituição.

Pelo exposto, verifica-se que a Constituição Federal é o fundamento de todo o Sistema Jurídico Nacional e o intérprete supremo da Constituição (STF) situa-se como a estrutura estatal de maior relevância e máxima responsável pela dinâmica normativa e institucional da ordem jurídica, política e social.

Pode-se constatar, portanto, que o STF, como Corte Constitucional brasileira, ocupa uma posição central e especial entre os órgãos constitucionais da República federativa do Brasil, na medida em que seus amplos poderes hermenêuticos, somado à suas funções dentro do sistema jurídico, bem como a sua condição de órgão político, lhe permite ser o guardião do Sistema Jurídico, do Ordenamento Jurídico Nacional e do projeto normativo, político e ideológico expresso na Constituição.

Sobre o STF recai a responsabilidade política de zelar pela imortalidade normativa da Constituição e pela sua indisponibilidade política. Além disso, seus poderes hermenêuticos devem ser amplos, para que a Constituição Federal não se torne uma folha de papel. 
Com efeito, verifica-se que o STF possui papel primordial no Sistema Jurídico Nacional, visto que espelha o atual nível de desenvolvimento, não só jurídico, mas também cultural, político e moral da comunidade política brasileira. De sorte, o STF consiste num meio de zelar pela funcionalidade e "boa saúde" do sistema jurídico.

Por outro lado, vale dizer que o STF não está acima do bem e do mal, pelo contrário, está e permanece sujeito a limites constitucionais, políticos e institucionais, a saber: a vinculação às regras e aos deveres comuns a todo órgão e autoridade jurisdicional; as diretrizes e princípios do sistema jurídico nacional; a moral positiva; a competência dos outros dois poderes; e, por fim, a justificação das suas decisões.

\section{SÚMULA Nº 11 DO STF E QUESTÕES CONTROVERTIDAS}

A súmula vinculante se propõe a reafirmar a missão do Supremo Tribunal Federal de intérprete máximo da Constituição Federal, pretendendo conferir uniformidade de interpretação ao direito constitucional. $\mathrm{O}$ instituto, ao mesmo tempo em que resgata que o STF constitui o órgão de cúpula do Poder Judiciário remete ao seu papel de Corte Constitucional.

Nos termos do art. 102 da Constituição Federal de 1988, ao Supremo Tribunal Federal compete a guarda da Constituição. Desde 1890, quando de sua criação, com o advento da República e em todas as constituições que se seguiram, o STF esteve previsto como a última instância do Poder Judiciário ao qual incumbe tomar a última decisão sobre as questões constitucionais (ZAVASCKI, 2001, p.15).

Enquanto instância máxima do Poder Judiciário, incumbe ao STF decidir como tribunal recursal os casos concretos que contemplem matéria constitucional. Como Corte Constitucional lhe afeta dar a palavra final sobre a constitucionalidade das leis, pretendendo conferir unidade ao direito.

A súmula vinculante surge num importante momento de crise do Estado Social Democrático que passa a revisar os seus fundamentos enquanto provedor das carências de uma sociedade globalizada e complexa que resiste em ocupar uma posição de espectadora das decisões estatais. A sociedade contemporânea questiona o papel do Estado e das instituições, dos seus direitos e deveres no novo formato que vai emergindo da crise da modernidade e, principalmente, exige uma participação mais efetiva das instâncias formais de poder na solução dos novos conflitos surgidos com a contemporaneidade. 
Para fazer frente às exigências do novo esquema social o Poder Judiciário entendeu por adotar mecanismos de garantia da celeridade processual e da igualdade na apreciação do direito dos jurisdicionados. Com a finalidade de conferir maior presteza na análise dos pleitos judiciais e de deferir unidade na interpretação do direito constitucional, a súmula de efeitos vinculantes foi inserida no direito brasileiro pela Emenda Constitucional $n^{\circ} 45 / 2004$. Nesse contexto, é que se torna importante analisar se a súmula de efeitos vinculantes consiste em uma inserção afinada com o atual momento de rediscussão do papel do Estado brasileiro e das suas instituições.

O elemento fundamental para o início do processo de criação de súmula vinculante consiste na existência de reiteradas decisões proferidas pelo Supremo Tribunal Federal em um mesmo sentido. Caso as decisões sobre determinada matéria ainda guardem divergência entre as Turmas do STF, ou ainda que proferidas num mesmo sentido, não forem expressivamente repetidos os casos, não estará preenchido o requisito para a edição de súmula vinculante. Deverá o STF avaliar quando suas decisões estão suficientemente maduras para a edição de uma súmula vinculante, incumbindo-lhe um dever de cautela que não poderia ser expresso na lei pelo julgamento de um número determinado de casos.

O instituto das súmulas vinculantes, disposto no artigo 103-A da Constituição Federal, possui como requisito básico para a sua edição que hajam decisões reiteradas sobre matéria constitucional, contrário ao que se observa na edição da Súmula Vinculante $\mathrm{n}^{\mathrm{o}} 11$ da qual apenas uma única decisão, anulação do HC 91952, teria motivado a sua formulação.

Outros requisitos também não teriam sido observados, como: controvérsia atual entre órgãos judiciários ou entre esses e a administração pública; grave insegurança jurídica; e, relevante multiplicação de processo sobre questões idênticas.

Mesmo que a decisão do HC 91952 tenha sido suficiente para a edição desta tão importante súmula, outro vício, em tese, se observa: a matéria da Súmula Vinculante $n^{\circ} 11$ foi mais ampla do que o contido no Habeas Corpus apreciado.

O STF, através da súmula, partiu de um caso específico (ofensa à dignidade humana pelo uso de algemas no Tribunal do Júri), para o caso geral (uso de algemas pela autoridade policial). Conclui-se, então, que o STF legislou sobre o tema, inclusive criando um novo crime, impondo critérios inexistentes a serem seguidos pelos agentes do Estado no emprego de algemas.

Esta matéria ao ser tema de súmula vinculante vem a eliminar e restringir qualquer discussão futura que possa vir ocorrer em instâncias inferiores, ou até mesmo a matéria ser tema 
de elaboração de lei pelo Poder Legislativo, conforme afirma a Delegada de Polícia Federal Arryanne Queiroz (2008).

A edição desta súmula somente seria possível se esta restringisse ao emprego de algemas em júri. No que tange as prisões cautelares não haveria essa possibilidade, porque não existem, no STF, julgados que comprovem a existência de matéria controvertida.

Para o uso de algemas foi considerado pelo STF como sendo de questão constitucional, assim, não cabendo a lei federal, tampouco a decreto disciplinar a matéria, não permitindo, também, por analogia uma reação legislativa neste momento, pois seria contrária a súmula já editada (informação verbal), em contrário sensu ao disposto por Arryanne .

Outra crítica à Súmula Vinculante $\mathrm{n}^{\mathrm{o}} 11$, uma delas considerando perigosa a comparação que o STF fez do uso indevido de algemas com a Teoria das Provas Ilícitas, pois o algemar sem motivação ou motivação anulada pelo Tribunal poderá anular todo o julgamento, ou até mesmo todo o processo (QUEIROZ, 2008).

Essa análise realizada pelo STF faz com que o advogado do réu, a qualquer mínimo descumprimento desta súmula, levantasse reclamação junto ao STF, atolando o Tribunal Superior. O emprego de algemas, conforme o Manual sobre Uso de Algemas da Polícia Federal visa à segurança e preservação da integridade física do preso, do policial e dos terceiros, evitando repercussões desastrosas, como: suicídios, fugas etc. As algemas evitam, ainda, atos irracionais dos presos, pois para ele, seria impossível prever o comportamento do preso, porque a prisão possui elevado grau de estresse, portanto recomenda-se que se faça o uso sempre de algemas tanto nas prisões como para os presos conduzidos (QUEIROZ, 2008).

Por questão de política constitucional, o papel do Supremo Tribunal Federal como instituição republicana tem sido definido nas últimas alterações da Constituição Federal de maneira bastante clara como Corte Constitucional. Nesse formato, compete ao STF a objetivação do direito para a "compatibilização vertical” (MARINONI, 2008) das decisões judiciais.

Entende-se por compatibilização vertical, a forma com que os juízos e tribunais do país decidem seus casos com assento na decisão paradigma proferida pelos tribunais superiores. Exatamente finalizando perpetrar esta escolha política adotada pelo constitucionalismo moderno de definir o STF como tribunal incumbido principalmente (ou exclusivamente) da aferição in abstrato da constitucionalidade das leis e de sua melhor interpretação em vista da Constituição Federal, foram criados dispositivos legais que possibilitam e ao mesmo tempo vinculam os tribunais a seguir a linha da jurisprudência do Supremo Tribunal Federal. 
O art. 557 do CPC, com redação dada pela Lei $n^{\circ}$ 9.756, de 17.12.1998, permite ao relator, nos juízos colegiados, negar seguimento a recurso em confronto com súmula ou jurisprudência do STJ ou do STF, bem como, lhe autoriza no caso de a decisão recorrida estar em manifesto confronto com a súmula ou a jurisprudência dominante daqueles tribunais, dar provimento ao recurso. $\mathrm{O}$ art. 518, $\S 1^{\circ}$ do CPC, com redação da Lei $n^{\circ} 11.276 / 2006$, prevê hipótese de negativa de recebimento do recurso de apelação se a sentença estiver de acordo com súmula do Superior Tribunal de Justiça ou do Supremo Tribunal Federal. Por sua vez, o art. 103-A da Constituição Federal, introduzido pela Emenda Constitucional $\mathrm{n}^{\circ} 45$, de 30/12/2004, permitiu ao Supremo Tribunal Federal editar súmulas com efeitos vinculantes em matéria constitucional (MARINONI, 1998; MIDIDIEIRO, 2008, p. 19).

O efeito vinculante dos precedentes do Supremo Tribunal Federal, portanto, já estava assentado em dispositivos legais. Igualmente, este efeito já era conhecido das decisões definitivas de mérito proferidas em sede de ação declaratória de constitucionalidade, conforme previa o art. 102, $\S 2^{\circ}$ da CF, com a antiga redação dada pela Emenda Constitucional n 3, de 17/01/1993, estendendo-se aos demais órgãos do Poder Judiciário e do Poder Executivo. Não obstante a Constituição Federal ter omitido a previsão de efeito vinculante para as decisões definitivas de mérito proferidas em ação direta de inconstitucionalidade, a interpretação do STF sempre foi de estender estes efeitos também a esta ação.

Efetivamente, com a Emenda Constitucional no 45, de 2004, o $2^{\circ}$ do art. 102 da CF recebeu nova redação, contemplando a ação declaratória de constitucionalidade e a ação declaratória de inconstitucionalidade, cujo efeito vinculante das decisões definitivas de mérito proferidas nestas ações fora previsto para todos os demais órgãos do Poder Judiciário e da Administração.

A ADI e ADC têm assento em controvérsia jurisprudencial quanto à melhor interpretação da lei in abstrato, ou na discussão acerca de sua constitucionalidade ou inconstitucionalidade, cuja decisão será proferida pelo STF em um processo objetivo - sem partes diretamente interessadas na solução de um caso concreto. A súmula de efeitos vinculantes tem por base a reiterada divergência jurisprudencial sobre matéria constitucional coletada no controle difuso-concreto procedido pelos juízes e tribunais do país. Sua distinção fundamental em relação às referidas ações constitucionais reside no fato de que não está em caso necessariamente a constitucionalidade/inconstitucionalidade de uma lei, mas sim, a melhor interpretação do direito constitucional em determinados casos concretos que dada a 
representatividade e repetição, passam a servir de paradigma para todos os demais casos que suscitarem idêntico tipo de controvérsia.

Portanto, enquanto a ADI e a ADC trabalham efeitos vinculantes num plano mais geral e abstrato de conformação da lei ao sistema do direito constitucional, a súmula vinculante culmina num enunciado do que compreende o Supremo Tribunal Federal ser a melhor interpretação do direito constitucional para determinados casos concretos. É nesse sentido que a súmula vinculante possui uma ingerência mais abrangente e ao mesmo tempo pormenorizada nas análises que passarão a ser feitas pelos demais órgãos do Poder Judiciário e pela administração pública, interferindo de forma diretiva nos juízos de particularidade que serão realizados no caso concreto.

A súmula com efeitos vinculantes reafirmou uma posição política que veio sendo afirmada pelo Supremo Tribunal Federal sob o fundamento de conferir unidade ao direito e celeridade na apreciação das demandas judiciais. Essa intenção de planificação da interpretação do direito já vinha trabalhada em outros dispositivos legais e constitucionais de modo que a discussão polêmica acerca da imperatividade dos efeitos de uma súmula vinculante foi atenuada pela precedência desses dispositivos normatizadores.

O processo de criação da súmula vinculante é objetivo, assim como o processo da ADI, da ADC e do descumprimento de preceito fundamental. Neste tipo de processo não há a presença de partes, mas de entes legitimados a provocar a decisão do STF, importando, sobretudo, a tutela do ordenamento jurídico constitucional abstratamente considerado. Os legitimados à propositura de súmula vinculante não defendem interesses próprios, embora possam defender os interesses institucionais que representam e por isso não exercerão o contraditório e a ampla defesa (LEITE, 2007, p.135).

$\mathrm{Na}$ análise de viabilidade da súmula vinculante, o STF analisa a melhor aplicação do direito constitucional a um determinado tipo de controvérsia constitucional cujo entendimento, uma vez firmado, importará em vinculação não apenas para sujeitos determinados e interessados na solução de uma controvérsia, mas em alteração do ordenamento jurídico que terá acrescentado um novo entendimento acerca da aplicação do direito constitucional.

Esta breve abordagem do tratamento constitucional deferido à súmula vinculante tem por objetivo apenas o resgate de sua confirmação e características no ordenamento pátrio a fim de viabilizar com esse conhecimento prévio, a análise de seus propósitos e a problemática que enseja. 


\section{APLICABILIDADE À ATIVIDADE POLICIAL E AFRONTA A TUTELA DA HONRA E IMAGEM DOS PRESOS}

Com a decisão da Corte, deixar mais explicitada o seu entendimento sobre o uso generalizado de algemas, diante do que considerou uso abusivo, nos últimos tempos, em que pessoas detidas vêm sendo algemadas e expostas aos flashes da mídia. Enfim, manifestou a sua preocupação com o efeito prático da súmula sobre a autoridade policial, no ato da prisão, ou seja, que a súmula possa vir a servir como elemento desestabilizador do trabalho da polícia (2008).

Importante lembrar que, muitas vezes, um agente policial tem de prender, sozinho, um criminoso, correndo risco. Lembra-se também, que é interesse do Estado conter a criminalidade, para isso, é necessário utilizar a força, quando necessário. Para a Polícia Militar o que mais importa é o ato da prisão dos infratores da lei, que mesmo sendo um ato que viole a dignidade da pessoa humana, haja vista ser a liberdade o fator natural do homem, observa-se que se a prisão for amparada pela lei, não se justifica a não utilização das algemas pelos órgãos policiais, entretanto o excesso em seu emprego caracterizaria em um atentado à liberdade de locomoção, crime de Abuso de Autoridade, Lei n ${ }^{\circ}$ 4898/65, além da responsabilidade civil e consequências disciplinares através de seus Regulamentos Disciplinares.

Assim, policial militar que fizer uso das algemas deverá justificar por escrito o feito, podendo ser no próprio Relatório de Serviço Operacional, o RSO; devendo, ainda, atentar para a exposição indevida do preso à mídia, principalmente se algemado.

Outra questão levada a efeito para a Polícia Militar é no que tange a escolta de presos, pois seria muito difícil a substituição das algemas pelo reforço policial, por que para cada preso algemado conduzido deve ser empregado, no mínimo, um policial militar. Com o proposto pela referida súmula, a condução dos infratores escoltados sem as algemas faria com que se aumentasse o numero de policiais empregados, algo descabido na atualidade, devido às diversas atividades desempenhadas pela polícia.

Outra questão surge após a edição da Súmula Vinculante nº11, da qual o Promotor de Justiça do Distrito Federal Rodrigo de Abreu Fudoli colocou com propriedade, no que tange ao "fundado receio de fuga ou de perigo à integridade física de qualquer pessoa". 


\begin{abstract}
Será que o STF aceitará que a pessoa presa ou que deva ser presa seja algemada com base exclusivamente na natureza do crime, por exemplo, homicidas, poderiam ser sempre algemados, ainda que bem comportados durante o processo, ao passo que os estelionatários não, ou será exigido, para a colocação de algemas no preso uma conduta concreta demonstrando periculosidade (exemplo: o réu que olha de forma ameaçadora para a vítima em audiência)? E mais: tendo em vista o inato desejo de liberdade do ser humano, será que não haveria fundado receio de fuga em toda execução de uma prisão (em flagrante ou não), e mesmo em toda situação na qual o preso vislumbre a possibilidade de fuga (por exemplo, em uma audiência judicial à qual comparece escoltado)? (FUDOLLI, 2008).
\end{abstract}

Isto faz com que se analise ao se empregar as algemas deverá ser pelo critério da possibilidade de uma atitude adversa pelo preso por aquilo que ele cometeu (análise implícita), ou por aquilo que ele 'visivelmente' tem demonstrado através de suas atitudes (análise explícita). Independente da decisão a ser tomada pelo policial militar na ocorrência ou na escolta do preso em se fazer valer das algemas, haverá a necessidade que se haja a devida justificativa escrita por parte do agente do Estado.

A dúvida por parte do policial militar no uso ou não das algemas para uma prisão favorece a ele mesmo, pois isso é considerado como sendo um temor justificável. Exemplo disso são os casos de prisão em flagrante delito, que na dúvida, poderá o policial militar fundamentar posteriormente o uso das algemas, não se consubstanciando tal conduta como sendo crime de Abuso de Autoridade (informação verbal) (FUDOLLI, 2008). O crime de Abuso de Autoridade, pois deve se existir o dolo de agir contrário às normas, sendo fato atípico o emprego de algemas da qual o policial militar, na dúvida, utilizou crendo estar fazendo o correto, se justificando por escrito, não será passível de nulidade na fase judicial.

Tudo se resume na boa aplicação do princípio da proporcionalidade, que exige adequação, necessidade e ponderação da medida. Em todos os momentos em que (a) não patenteada a imprescindibilidade da medida coercitiva ou (b) a necessidade do uso de algemas ou ainda (c) quando evidente for seu uso imoderado, há flagrante violação ao princípio da proporcionalidade, caracterizando-se crime de abuso de autoridade. Cada caso concreto revelará o uso correto ou o abuso. Lógico que muitas vezes não é fácil distinguir o uso lícito do uso ilícito. Na dúvida, sabe-se que, não há que se falar em crime. De qualquer modo, o fundamental de tudo quanto foi exposto, é atentar para a busca do equilíbrio, da proporção e da razoabilidade. 


\section{CONCLUSÃO}

Acredita-se que o trabalho realizado nessa área foi capaz de restringir o universo de possibilidades deferidos pela linguagem, reduzindo o campo de atuação do julgador e assim ao conceber, desconsidera a inevitabilidade da condição hermenêutica do ser humano.

A finalidade da Súmula Vinculante ${ }^{\circ} 11$ do STF foi atender a um fundamento político que clamava uma maior celeridade e efetividade da prestação jurisdicional, reafirmando o papel como intérprete máximo da Constituição, na medida em que lhe dispensou em grande medida de cumprir a função revisional.

O problema do método é apenas anunciativo de uma deformidade do instituto que diz respeito à sua natureza jurídica de norma geral e abstrata. Tal como prevê a doutrina de Kelsen, a súmula vinculante pretende, a partir de um enunciado prescritivo, estabelecer uma hierarquia entre a norma superior e a norma inferior. A norma superior é representada pela súmula vinculante a norma inferior pela decisão que o juiz deverá adotar no caso concreto.

Nesse sentido a teoria dos princípios ganha uma sistematização maior em Alexy (2008). Para ele, a aplicação de princípios segue um método específico, que se torna um verdadeiro dogma hermenêutico - para nossa Suprema Corte, inclusive, ainda que muitas vezes aplicado de modo bastante pessoal por alguns juízes e ministros -, que ficou conhecido por “sopesamento". Alexy (2008) propõe, para a aplicação de princípios em casos concretos que não podem ser resolvidos por regras em sua estrutura "tudo ou nada" (hard cases), um método trifásico que mede a aplicabilidade e direciona o uso de princípios constitucionais ou supraconstitucionais em casos concretos.

Todavia, a súmula vinculante pretende esgotar em seu enunciado, com natureza jurídica de norma geral e abstrata, o "quadro das leituras possíveis", conforme referido por Kelsen, finalizando, assim, evitar que a liberdade de interpretação dos julgadores venha a originar decisões divergentes acerca de um mesmo instituto jurídico.

Nesse contexto as instituições policiais militares, reafirmam os critérios objetivos dispostos na súmula a serem avaliados pelo policial militar no momento de se decidir em fazer uso ou não das algemas, e se usada, citar a justificação em documento específico ou relatório operacional. Esta readequação é importante para as polícias, pois de um algemamento injustificado, poderá se abrir a possibilidade de anular a prisão do detido, ou até mesmo acarretar a nulidade de todo o processo do réu pelo Judiciário. A polícia possui o Poder de Polícia, poder este não absoluto ou ilimitado, mas sim um poder que deve ser amparado 
quanto ao seu uso pela legalidade e motivação do ato. A força é quesito necessário para a polícia cumprir sua função constitucional de preservação da segurança pública, seu excesso é punível, exemplo: abusar do uso de algemas.

O objetivo da súmula é sim dar maior segurança jurídica ao emprego de algemas pelos órgãos policiais, em consonância com os Direitos Fundamentais da Pessoa Humana consagrados pelo art. $5^{\circ}$ da Constituição Federal de 1988, visando à legalidade dos atos de polícia e a restrição a casos específicos à liberdade da pessoa através da boa aplicação do princípio da proporcionalidade, que exige adequação, necessidade e ponderação da medida. O STF analisando a melhor aplicação do direito constitucional a um determinado tipo de controvérsia constitucional cujo entendimento, uma vez firmado, importará em vinculação não apenas para sujeitos determinados e interessados na solução de uma controvérsia, resumindo-se na boa aplicação do princípio da proporcionalidade.

\section{REFERÊNCIAS}

ALEXY, R. Teoria dos direito fundamentais. São Paulo: Malheiros, 2008.

BAKHTIN, M. Marxismo e filosofia da linguagem. São Paulo: Hucitec, 1995.

BRASIL. Constituição (1988). Constituição da República Federativa do Brasil. Brasília, DF: Senado Federal, 1988.

BRASIL. Decreto-lei no 4.657, de 4 de setembro de 1942. Lei de Introdução ao Código Civil Brasileiro.

BRASIL. Emenda Constitucional no 3, de 17 de janeiro de 1993. Altera os arts. 40, 42, 102, 103, 155, 156, 160, 167 da Constituição Federal.

BRASIL. Emenda Constitucional $\mathrm{n}^{\circ} 45$, de 30 de dezembro de 2004. Altera dispositivos dos arts. $5^{\circ}, 36,52,92,93,95,98,99,102,103,104,105,107,109,111,112,114,115,125,126$, 127, 128, 129, 134 e 168 da Constituição Federal, e acrescenta os arts. 103-A, 103B, 111-A e 130-A, e dá outras providências.

BRASIL. Lei nº 5.869, de 11 de janeiro de 1973. Institui o Código de Processo Civil.

BRASIL. Lei $\mathrm{n}^{\circ}$ 9.756, de 17 de dezembro de 1998. Dispõe sobre o processamento de recursos no âmbito dos tribunais.

BRASIL. Lei $\mathrm{n}^{\mathrm{o}} 11.276$, de 7 de fevereiro de 2006. Altera os arts. 504, 506, 515 e 518 da Lei no 5.869, de 11 de janeiro de 1973 - Código de Processo Civil, relativamente à forma de 
interposição de recursos, ao saneamento de nulidades processuais, ao recebimento de recurso de apelação e a outras questões.

BRASIL. Lei n ${ }^{\circ} 11.417$, de 19 de dezembro de 2006. Regulamenta o art. 103-A da Constituição Federal e altera a Lei no 9.784, de 29 de janeiro de 1999, disciplinando a edição, a revisão e o cancelamento de enunciado de súmula vinculante pelo Supremo Tribunal Federal, e dá outras providências.

DILTHEY, W. A construção do mundo histórico nas ciências humanas. São Paulo: Unesp, 2010.

DWORKIN, Ronald. Levando os Direitos a Sério. São Paulo: Martins Fontes, 2010.

FUDOLLI, Rodrigo de Abreu. "Uso de algemas: a Súmula Vinculante $\mathrm{n}^{\circ} 11$, do STF". JusNavigandi. Postado em: agosto de 2008. Disponível em: http://jus2.uol.com.br/doutrina/texto.asp?id=11625. Acesso em: 12 de novembro de 2008. Acesso em: 10 dez de 2014.

LEITE, Glauco Salomão. Súmula vinculante e jurisdição constitucional brasileira. Rio de Janeiro: Forense, 2007.

FERRAZ JUNIOR, T. S. Introdução ao estudo do direito: técnica, decisão, dominação. São Paulo: Atlas, 2008.

GADAMER, H. G. Verdade e método II: complementos e índice. Petrópolis: Vozes, 2002.

GADAMER, H. G. Verdade e método I: traços fundamentais de uma hermenêutica filosófica. Petrópolis: Vozes, 2007.

HEIDEGGER, M. Identidade e diferença. In: . Os pensadores: conferências e escritos filosóficos. São Paulo: Nova Cultural, 1999. 
MARINONI, Luiz Guilherme. MIDIDIERO, Daniel. Repercussão Geral no Recurso Extraordinário. 2a edição. São Paulo: Editora Revista dos Tribunais, 2008.

MIRANDA, Jorge. Direito Constitucional e Teoria da Constituição. $3^{\circ}$ Ed, Coimbra: Editora Almedina, 1999.

QUEIROZ, Arryanne. "Uso de algemas: Súmula Vinculante 11, do Supremo, é inconstitucional". Revista Consultor Juridico. Postado em: 21 de agosto de 2008. Disponível em: http://www.conjur.com.br/static/text/69133,1. Acesso em: $01 \mathrm{dez}$ de 2014.

RICOEUR, P. Du texte à l'action II: essais d'herméneutique. Paris: Seuil, 1986.

2011

Teoria da interpretação: o discurso e o excesso de significação. Lisboa: Edições 70,

SCHLEIERMACHER, Friedrich D. E. Hermenêutica: a arte e técnica da interpretação.

TEUBENER, G. O direito como sistema autopoiético. Lisboa: Calouste Gulbenkian, 1993.

ZAVASCKI, Teori. Eficácia das sentenças na jurisdição constitucional. São Paulo: Editora Revista dos Tribunais, 2001. 